\title{
CHOICE OF AN OPTIMAL MANAGEMENT STRATEGY OF TRANSPORT DEMAND USING MULTI-CRITERIA ANALYSIS: CITY OF ZAGREB CASE STUDY
}

\author{
Ljupko Šimunović ${ }^{1}$, Davor Brčić ${ }^{2}$, Huska Sadić ${ }^{3}$ \\ ${ }^{1,2,3}$ University of Zagreb, Faculty of Transport and Traffic Sciences, Vukelićeva 4, 10000 - Zagreb, Croatia
}

Received 29 August 2012; accepted 7 December 2012

\begin{abstract}
After initial enthusiasm by motor vehicles, society is lately increasingly noticing their shortcomings. Traffic problems caused by excessive use of cars, still represent a very serious and widespread problem, particularly in cities. Public opinion expresses dissatisfaction with the quality of the environment and traffic conditions. As the most important demand, the demand for human health stands out in the first place, and, consequently, the demand for sustainable transport development. The fact that the EU is involved in solving traffic problems by means of various directives and scientific research projects, points out the seriousness of the problem. Two solutions which are mainly used for solving traffic problems in cities are the construction or extension of existing transport infrastructure and traffic demand management (TDM). Traffic demand management is a new paradigm, which aims at reducing or transforming of traffic demand through reduction of unnecessary drives by cars and improvement of more efficient, healthier and, above all, cleaner forms of public and non-motorized transport. There is a whole range of methods for traffic demand management, such as Park \& Ride system, carpooling, carsharing, priority for the vehicles with specified number of passenger - HOV, teleworking, congestion charging, charging for use of road infrastructure, bicycling infrastructure improvement, etc. The topic of the work focuses on the choice of optimal traffic demand management strategies in the city of Zagreb using multi-criteria analysis.
\end{abstract}

Keywords: transport demand management, multi criteria analysis, City of Zagreb.

\section{Introduction}

Since in the city the places of work, residence and other activities are usually situated at different locations, there is an increasing need for mobility of the population. Increased mobility and inadequate traffic capacity (insufficient infrastructure and means of transport) lead to a series of negative consequences which are being felt in large cities. Unfortunately, the city of Zagreb follows the negative trends of contemporary European cities in the development of the transport system (there are more cars in the city center, the traffic jams are greater, as well as noise and pollution), causing lower quality of life in the city centers. Finding new solutions in transport planning and management, traffic problems can be alleviated or completely eliminated. The ultimate goal of traffic planning and management is sustainable mobility and transport development of such

${ }^{1}$ Corresponding author: ljupko.simunovic@fpz.hr 
transport concepts, which will not have adverse effects on humans in the future.

In the continuation of this paper, the optimal strategy of traffic demand management in the city of Zagreb will be selected using multicriteria analysis Analytic Hierarchy Process (AHP).

\section{Review and Characteristics of Transport Demand Management Strategies}

Transport demand management (TDM) is a concept to promote sustainable transport and manage the demand for car use by changing travellers' attitudes and behaviour. As appropriate name for traffic demand management, the most commonly used in terms in literature are the English terms “Transportation Demand Management" or “Travel Demand Management” (TDM), and names such as "Mobility Management" (MM) and "Congestion Management" (CM) (VTPI, 2010; $4^{\text {th }}$ RTD FP, 1999; US DOT, 1993). At the core of Transport demand management are "soft" measures like information and communication, organising services and coordinating activities of different partners. "Soft" measures most often enhance the effectiveness of "hard" measures within urban transport (e.g., new tram lines, new roads and new bike lanes). Transport demand management measures (in comparison to "hard" measures) do not necessarily require large financial investments and may have a high benefit-cost ratio (Baasch et al., 2012; Kaiser and Scholl, 2011).

Transport demand management aims at reducing and reshaping transport demand by reducing the unnecessary driving of passengers' cars, as well as at an improvement of efficiency, health and, above all, introduction of cleaner forms of public transportation. The Table 1 presents some transport demand management strategies.

\section{Table 1}

Transport Demand Management Strategies

\begin{tabular}{|l|}
\hline Strategy \\
\hline Alternating directions of travel lanes \\
\hline Alternate work schedule \\
\hline Flextime \\
\hline Compressed work week \\
\hline Telecommuting \\
\hline Congestion charging \\
\hline Road pricing \\
\hline Walking \\
\hline Bicycling \\
\hline Car sharing \\
\hline Ride sharing (carpooling) \\
\hline Vanpooling \\
\hline Transit \\
\hline Traffic Calming \\
\hline Ramp metering \\
\hline Park\&Ride \\
\hline Kiss\&Ride \\
\hline HOV, HOT \\
\hline Express bus service \\
\hline Intelligent Transportation System (ITS) \\
\hline Use of mass public transport \\
\hline Land use and zoning \\
\hline
\end{tabular}

Which of the transport demand management strategies is going to be used depends on the community, demographic, geographic, and political conditions. If possible, it is best to use a combination of different strategies. Combined effect of different transport demand management strategies has a greater synergistic effect than the sum of the effects of individual strategies. Individual strategies have a modest effect in terms of travel efficiency improvement. 
Today systematic transport demand management represents a socially responsible and environmentally conscious behavior, and it is reflected in:

- the reduction of the number of vehicles on roads;

- the reduction of the emissions of harmful gases;

- the reduction of the level of environmental pollution;

- $\quad$ increasing the fuel efficiency;

- the reduction of noise;

- prioritizing local public transport compared to individual transport;

- the reduction of congestions;

- the increase of the traffic flow;

- $\quad$ significant savings for road users.

\section{Choice of an Optimal Transport Demand Management Strategy Using Multi-Criteria Analysis}

Analytical Hierarchy Process (AHP) is one of the most popular and in recent years the most commonly used method for multi-criteria decision making (FOI, 2012; Forman and Selly, 2002; Saaty, 1980; Belton and Stewart, 2002). This method is intended for solving decision problems that involve multiple alternatives and a number of criteria. In decision making, multiple decision makers may be involved. Since the AHP method proved relatively successful in solving complex problems, a software package Expert Choice 11 (EC11) (Expert Chioce software; Expert Chioce Inc., 1982-2004) has been developed for its application. It has given a significant impetus to the development and the application of decision support systems and expert systems for solving problems of multi-attribute decision-making. It is a robust application designed for desktop computers, which allows priority sorting and alternatives prioritizing, and reliable decision-making about the alternatives for achieving the desired goals. Expert Choice software package can integrate data from Microsoft Excel, Microsoft Project and Oracle databases. It is useful for "what-if" scenario in strategic planning. Hierarchical model of AHP methods for the improvement of traffic mobility management in the cities is shown in Fig. 1.

Basically, it is a hierarchical structure, having the goal at the very top, and below it are the criteria and the sub-criteria. On the lower level of the hierarchical structures, there are the alternatives. In the model of the multiple criteria decision-making, which aims to improve mobility in the city of Zagreb, the criteria are: safety of participants, ecology, system availability, road network bandwidth and economic indicators. The following strategies have been offered as the alternatives: transit improvement, walking and bicycling improvement, carsharing, teleworking and flexible working hours.

Structuring the problem and comparing alternatives and criteria in pairs can be done in several ways using Expert Choice software. Fig. 2 shows the basic structural model for the improvement of the mobility in the city of Zagreb in the program Expert Choice window.

After defining the alternatives and determining the criteria, it is necessary to determine the importance of the criteria and their impact on the alternatives. At each level of the hierarchical structure, the elements of the structure are compared to one another in pairs, with the decision-makers' preference expressed according to an appropriate scale (Saaty-scale of the relative importance), having 5 degrees and 4 are sub-degrees of verbally described intensity and with corresponding numerical values for them, in the range 1-9. 
Based on the assessment of the relative importance of the elements of the appropriate level of the hierarchical problem structure using the appropriate mathematical models, the local priority (weight) criteria, sub-criteria and alternatives are calculated and after that synthesized into the overall priorities of the alternatives.
Fig. 3 shows the comparison of the relative importance of alternative "Transit Improvement" compared to the alternative "Walking and Cycling Improvement" with respect to the criterion of "Participants Safety". Comparing the remaining pairs of alternatives has been conducted in the same way.

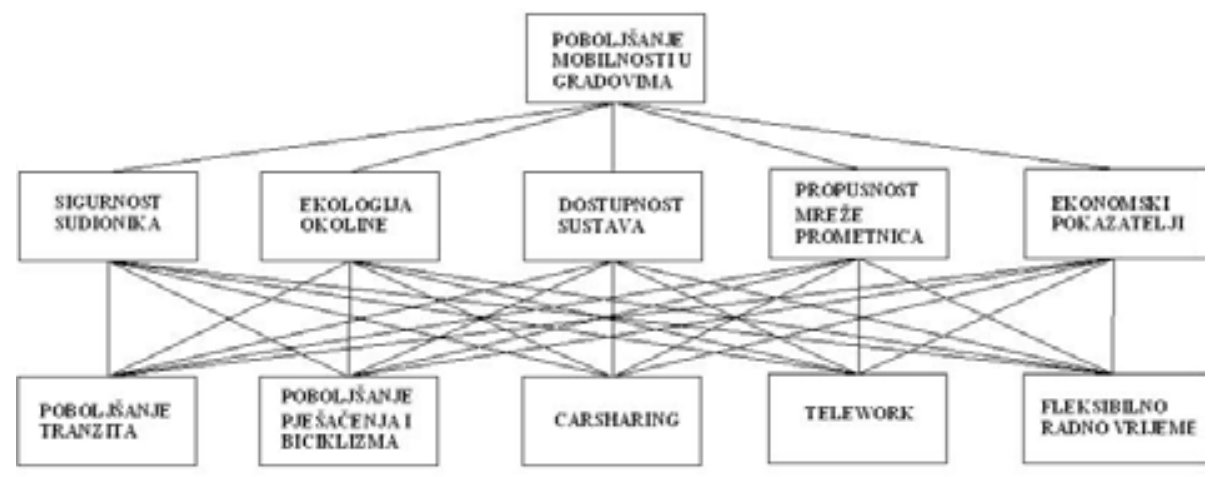

Fig. 1.

Model of the Multiple Criteria Decision Making for Improved Traffic Mobility Management in the Cities

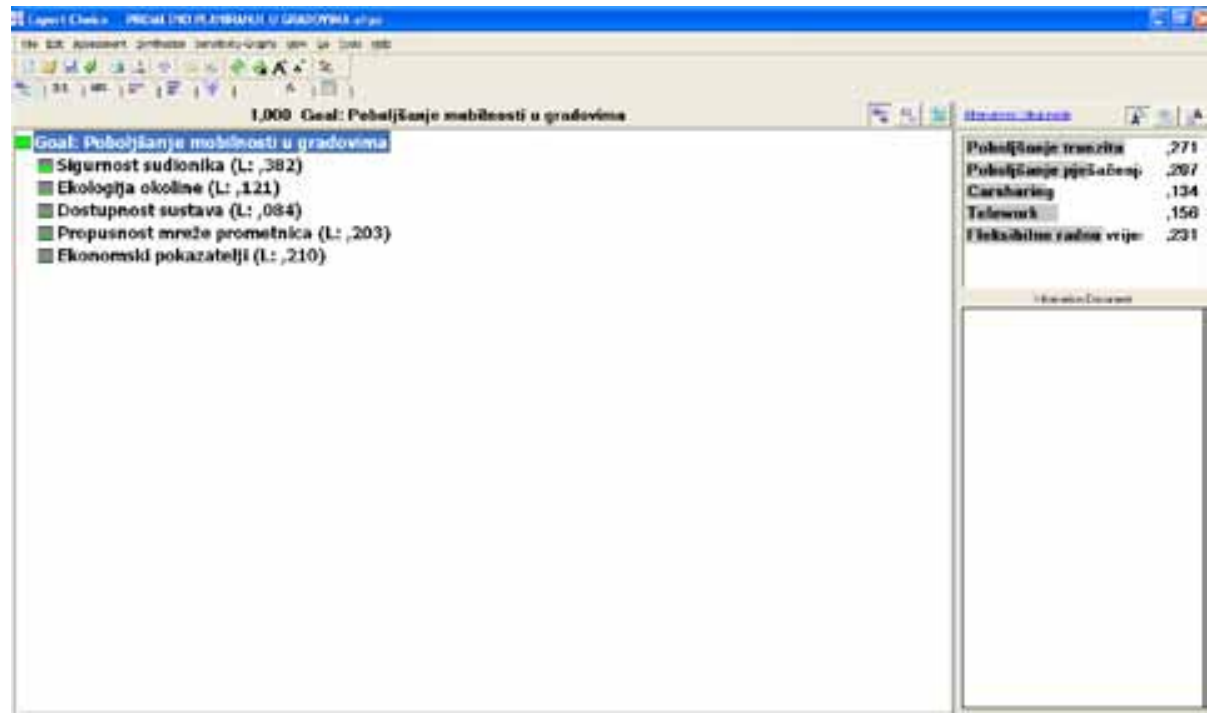

Fig. 2.

The Goal, Criteria and Alternatives in Model View Window, Expert Choice Program 
After determining the criteria, defining the alternatives, and setting up all the necessary weight, the sensitivity analysis is performed in order to determine the final optimal alternative. Results of the analysis are illustrated by the graphs: Dynamic, Performance, Gradient and Head-to-head.

Fig. 4 presents dynamic graphic display (Dynamic) of alternatives priority order depending on alternative weight of each criterion.

Fig. 5 displays the impact of certain criteria weight to the individual or the current overall alternatives order. Individual alternatives ranking is a change of priorities of an alternative under the influence of a criterion weight, and overall alternatives order represents an order of the alternatives affected by the weights of all the criteria.

Weight of each criterion is shown on the left $y$-axis, the effect of all the criteria and alternatives ranking are shown on the right $y$-axis of the graph, and the $\mathrm{x}$-axis shows the criteria. From the graph in Fig. 5 it is evident that the best solution to improve mobility in the city is an alternative "Transit Improvement". The greatest impact on the choice of this alternative had the following criteria: system availability, capacity and safety of the participants, while the ecology criteria and the economic indicators had the smallest impact on its choice. The lowest ranked alternative for transport demand management is "Carsharing". The greatest impact on the selection of this alternative have the criteria permeability and ecology, and traffic safety has the lowest impact.

Changes in (gradient) weight of each criterion influence the priority order of each alternative as a strategy for traffic management. The intensity of their impact is different for different alternatives. The graph Gradient Sensitivity in Fig. 6 shows the impact on the choice of a particular alternative of the criteria "Roads network bandwidth," with the weight of $20 \%$. Having compared the

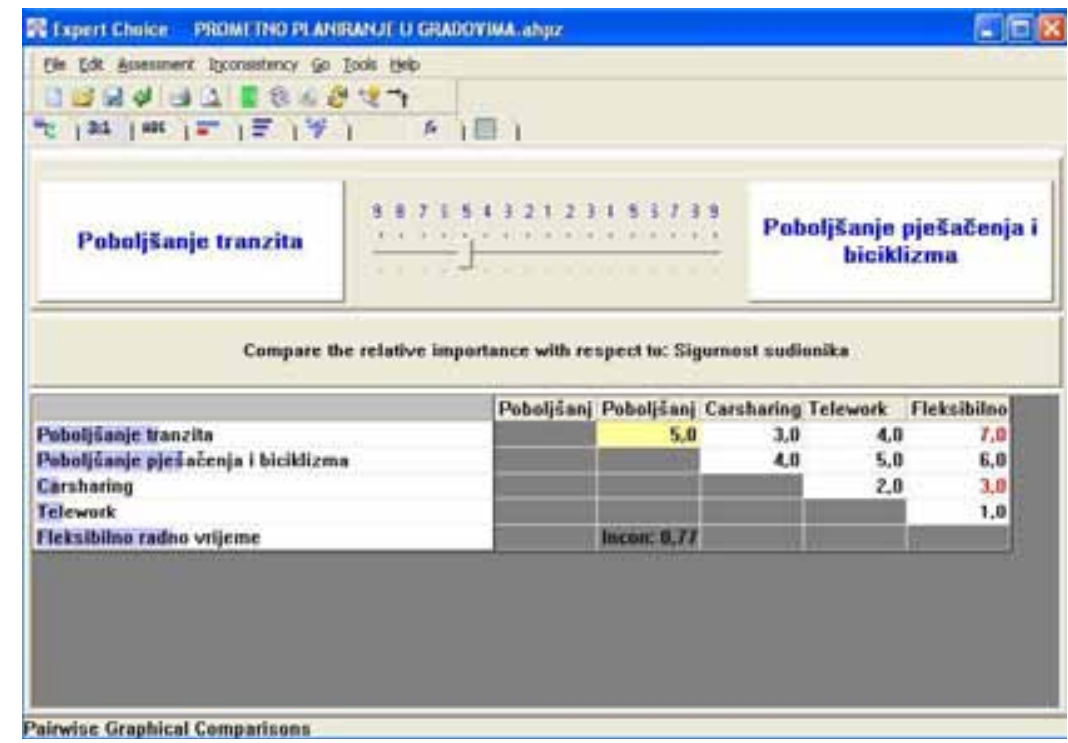

Fig. 3.

Procedure of Pairwise Comparison of the Alternatives (PAIRWISE) 


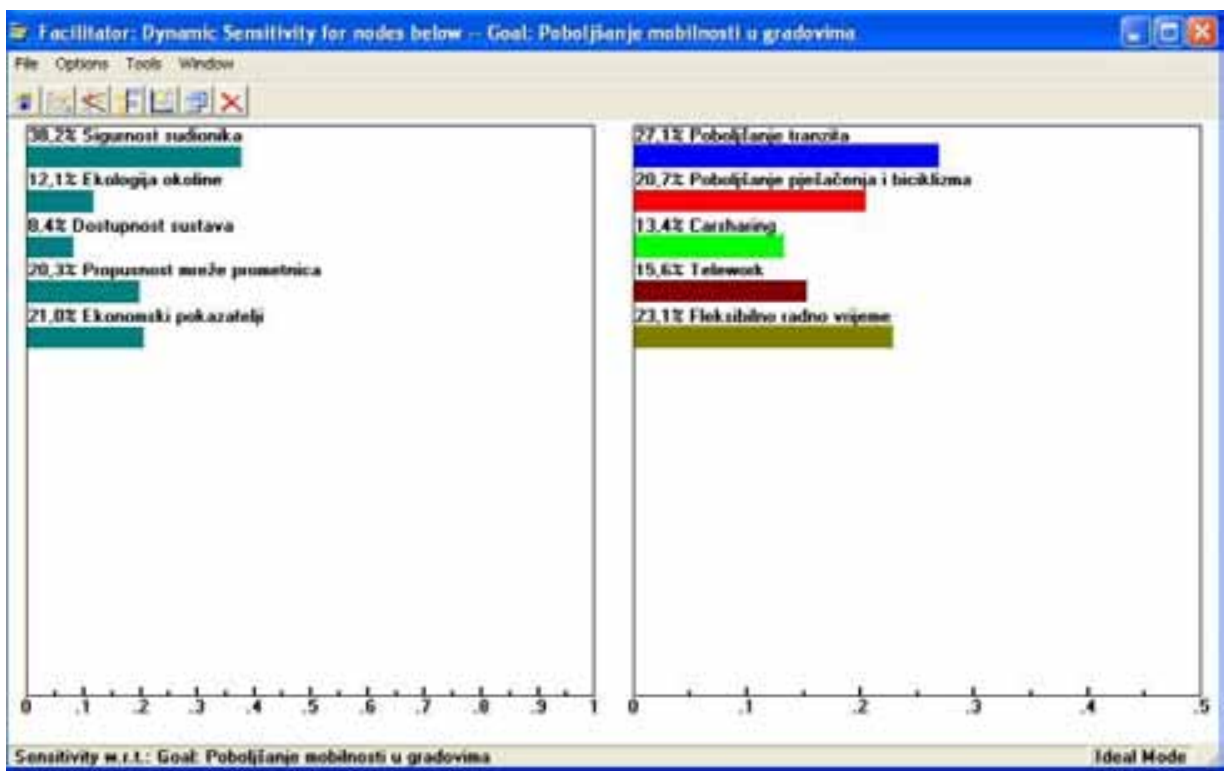

Fig. 4.

Graphical Display of the Importance of the Criteria (Left) for Alternatives Priority (Right)

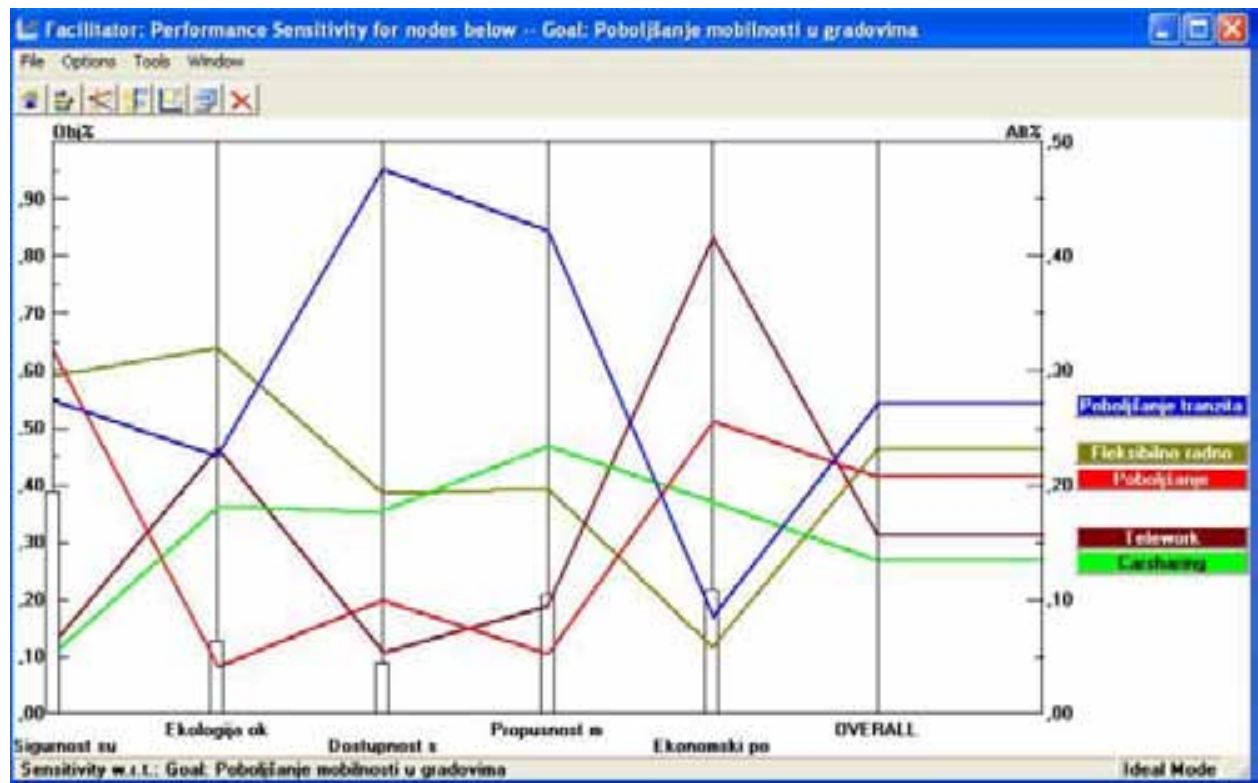

Fig. 5.

Performance - Graphical Display of the Criteria Impact on the Alternatives and their Overall Priority 
"Teleworking" and "Carsharing" alternatives on the graph, it can be seen that the "Teleworking" alternative has an advantage over the alternatives "Carsharing." Providing a greater weight to the "Roads network bandwidth" criterion changes the ratio in favor of "Carsharing." Weight change of the criteria "Roads network bandwidth", more or less, has a very little effect on the change of the priorities of some other alternative, such as "Flexible working hours."

If we want to manage the transport demand in the city by increasing the network bandwidth capacity, it is necessary to improve transit in the first place, then introduce carsharing, followed by flexible working hours, teleworking, and ultimately improve the conditions for walking and cycling.

In Fig. 7 (Head to Head) rectangular surfaces show the relationship of the alternatives against the given criteria. If one alternative predominates, the rectangular surface will illustrate how better this alternative is. Have one alternative "Carsharing" and another alternative "Walking and Cycling Improvement". The right side of the image shows that, according to the "Safety of the Participants" criterion, the "Walking Improvement" alternative is better than the alternative "Carsharing", which is indicated by the rectangular area on the right. The ecology criterion, system availability and roads network bandwidth tend to follow the "Carsharing" alternative which is illustrated by rectangles on the side of the alternatives.

The overall decision on the "Carsharing" and "Walking Improvement" alternatives tends to follow the "Walking Improvement" alternatives, which can be seen from the last rectangle "Overall" in Fig. 7.

AHP method is one of the popular methods also because of its ability to identify and analyze the inconsistencies of the decision-maker in the process of comparing the elements of the hierarchy (FOI, 2012; Saaty, 1980; Šimunović et al., 2010).

\section{Discussion}

Out of total of five criteria, which have been selected for this model, the utmost importance/ weight was given to the criterion of the safety of the participants $(38.2 \%)$, followed by the economic indicators $(21 \%)$, road network bandwidth (20.3\%), ecology (12.1\%) and system availability (8.4\%), as it is evident from Fig. 4. The greater the importance of the criterion, the greater impact it has on the final selection of an alternative. Evaluation of the importance of individual criteria was conducted by means of a survey among experts in the field of transport. According to Fig. 5, with regard to the "Safety of participants" criterion in the city of Zagreb, it would be ideal to encourage walking and biking in the first place, and in the last place carsharing is suggested as the worst choice. Taking into account the economic indicators, it would be best to introduce teleworking, then improve walking and biking, after that carsharing, then improve transit, and as the last alternative, to introduce flexible working hours. After the economic indicators, the road network bandwidth criterion follows. The best network bandwidth can be achieved by the improvement of transit, then by the introduction of carsharing, and flexible working hours, by teleworking and ultimately by walking and cycling improvement. Given the criteria ecology of the environment, it would be optimal to introduce flexible working hours, then teleworking, and then to improve transit and introduce carsharing. The smallest weight was given to the criterion of system availability. For an optimal implementation of this criterion, it would be best to improve transit, and in the last place to introduce teleworking. Namely, it has been shown that arriving to the destination 


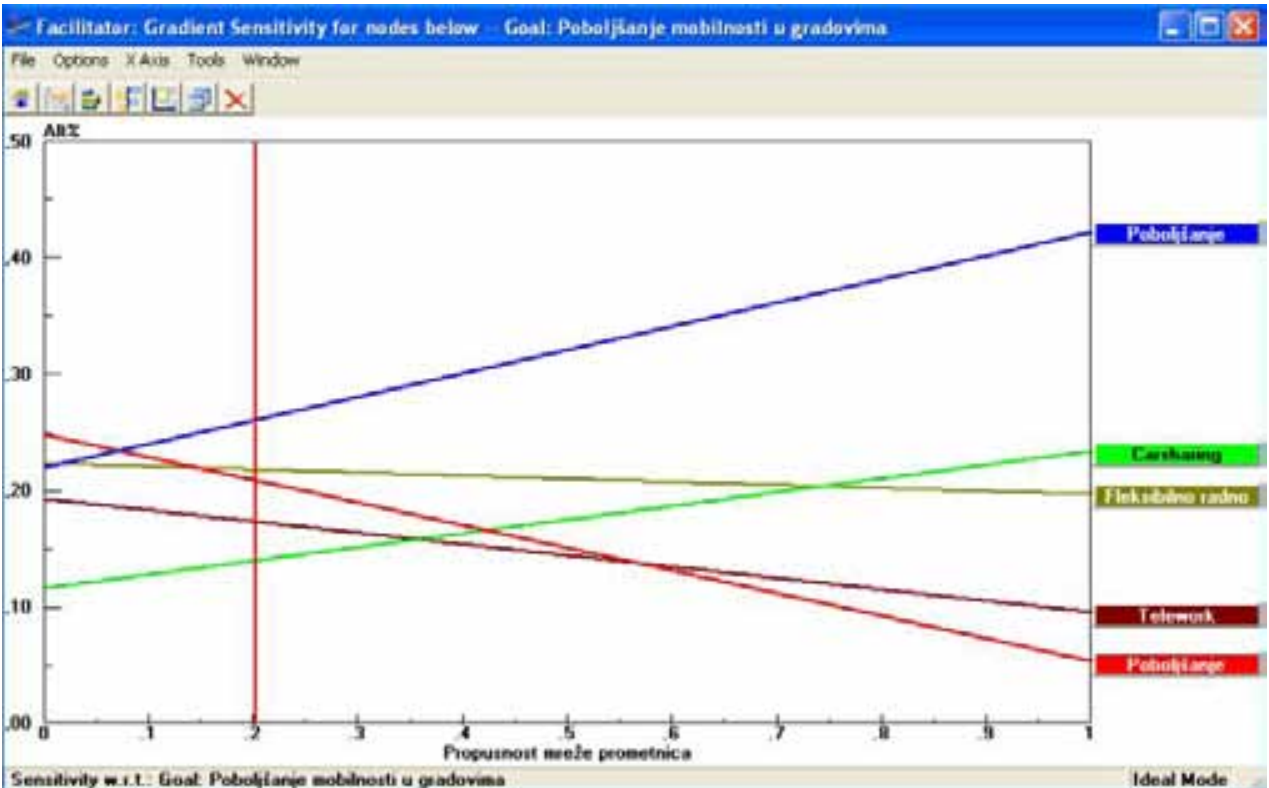

Fig. 6.

Preview of the Sensitivity of the Alternatives to a Weight Change of the

"Roads Network Bandwidth" Criterion

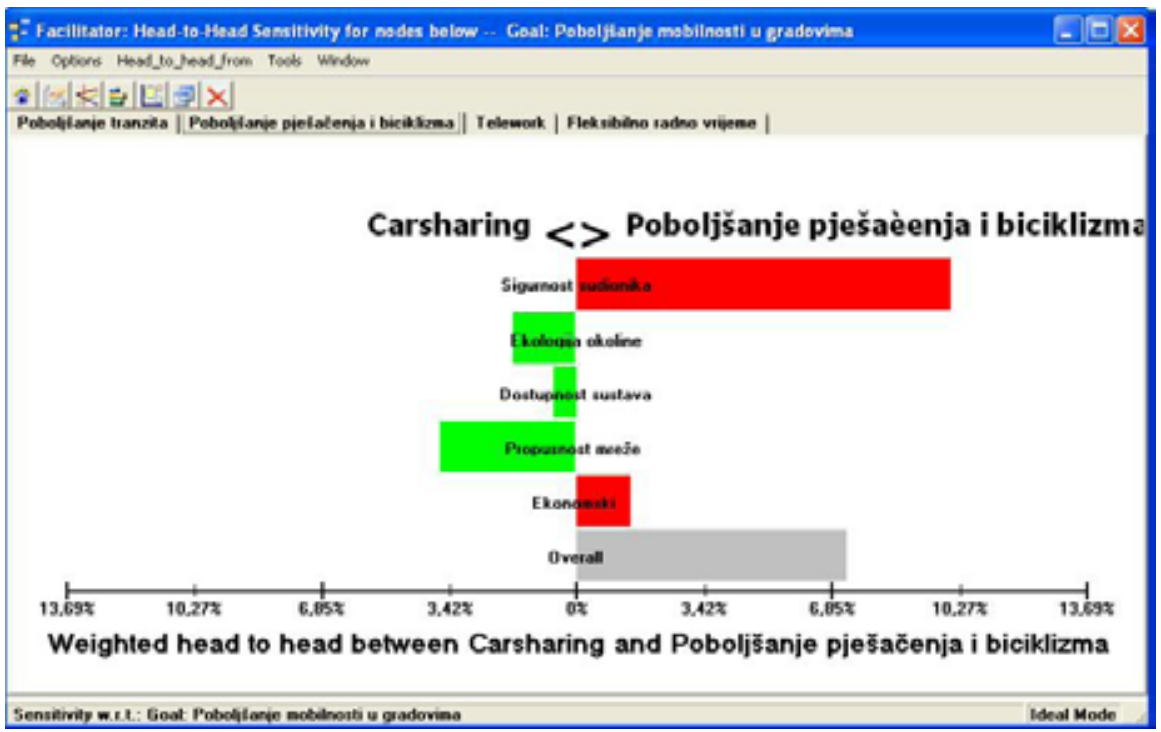

Fig. 7.

Parallel (Head to Head) Graphical Display of the Two Alternatives 
safer, cheaper and faster is more important for the users (passengers) than the system accessibility.

Evaluating the transport demand management alternatives in the city of Zagreb, on the basis of the set criteria, it is possible to rank them in order to select the optimal strategy for traffic management in the city of Zagreb. In accordance with the established model, the priority in the city of Zagreb has the transit improvement alternative (27.1\%), followed by flexible working hours $(23.1 \%)$, walking and cycling (20.7\%), teleworking (15.6\%) and carsharing (13.4\%) (Fig. 5).

For the full implementation of these strategies, it is necessary to provide a range of conditions, such as to construct the Park \& Ride system close to the public transport station, modernize means of public transport (increase speed, comfort, frequency, reliability, security), improve passengers' awareness, give priority to public transport, introduce the use of "smart" cards, etc. Unfortunately, most of the strategies that contribute to sustainable urban mobility have not been applied in an appropriate manner in the city of Zagreb.

\section{Conclusion}

The destination of numerous car trips is the city center, which is spatially and in the sense of traffic mostly already built and defined. Large increase in the number of motor vehicles inevitably leads to the serious difficulties in the conduct of transport system throughout the city, especially in the historic center, having the streets which were originally built for pedestrians and carriages and which cannot withstand such pressure. The solution for traffic problems has lately been sought in transport demand management (TDM).

Individually, the intermodal transport or transit proved to be the best solution for transport demand management in the city of Zagreb. Since individual strategies have modest effects in terms of improving the efficiency of travel, it is best to use a combination of several different strategies. Simultaneous use of multiple different transport demand management strategies has a cumulative and synergistic effect (their overall effect is greater than the sum of their individual effects), so it is important to assess mobility programs as a package, rather than as individual strategies.

\section{References}

Baasch, S.; Bossaert, E.; Ljungberg, C.; Papadimitriou, S.; Papaioannou, P.; Posch, K.H.; Rye, T.; Welsch, J. 2012. Mobility Management: A Definition. Available from Internet: <http://www.epomm.eu/docs/mmtools/MMDefinition/ MMDefinition_english.doc $>$.

Belton, V.; Stewart, T.J. 2002. Multi Criteria Decision Analysis - An Integrated Approach, Kluwer. Academic Publishers: Dordrecht. 151-159.

European Projects in the Fourth Framework Programme ( $4^{\text {th }}$ RTD FP). 1999. MOSAIC (Mobility Strategy Applications In the Community) and MOMENTUM (Mobility Management for the Urban Environment), Rijswijk/Aachen. Available from Internet: <http://www.gtkp.com/assets/ uploads/20091117-102648-3156-Usermanual.pdf >.

Expert Chioce software. Available from Internet: <http:// www.expertchoice.com>.

Experts Choice Inc. 1982-2004. Experts Choice, Arlington, VA, USA.

Fakultet organizacije i informatike (FOI), Varaždin. 2012. Nastavni materijali: AHP metoda-skripta, Matematički temelj AHP metode, Višekriterijsko odlučivanje, (in Croatian). Available from Internet: <http://old.foi. $\mathrm{hr} /$ studiji/dodiplomski/IS/kolegiji/mzvo/nastavni materijali.html>.

Forman, E.H.; Selly, M.A. 2002. Decision by Objectives, How to Convince others that You are right, World Scientific, 
New Yersey, London, Singapore, Hong Kong. Available from Internet: <http://mdm.gwu.edu/Forman/DBO.pdf $>$.

Kaiser, A.; Scholl, G. 2011. Mobility Management, Institute for Ecological Economy Research (IÖW), Berlin. Available from Internet: <http://www.scp-knowledge.eu/ sites/default/files/CORPUS\%20WP\%203\%20KU\%20 Mobility\%20Management\%20Final\%20version.pdf>.

Saaty, T.L. 1980. The Analytic Hierarchy Process, McGraw Hill International. New York, USA. 95 p.

Šimunović, Lj.; Grgurević, I.; Pašagić Škrinjar, J. 2010. Selecting optimal pedestrian crossing using multi-criteria decision-making, Promet - Traffic \& Transportation, 22(2): 105-116.

US Department of Transportaion. 1993. A Guidance Manual for Implementing Effective Employer-based Travel Demand Management Programs, Washington, USA. 3 p.

Victoria Transport Policy Institute. 2010. Online TDM Encyclopedia, Victoria, Canada. Available from Internet: <http://www.vtpi.org>.

IZBOR OPTIMALNE STRATEGIJE ZA UPRAVLJANJE SAOBRAĆAJNOM POTRAŽ N J M PRIMENOM VIŠEKRITERIJUMSKE ANALIZE: STUDIJA SLUČAJA - GRAD ZAGREB

\section{Ljupko Šimunović, Davor Brčić, Huska \\ Sadić}

Sažetak: Nakon početnog entuzijazma u korišćenju privatnih motornih vozila, društvo u poslednje vreme sve više uočava njihove nedostatke. Saobraćajni problemi nastali prevelikim korišćenjem privatnih vozila, danas predstavljaju vrlo ozbiljan i rasprostranjen problem, naročito u gradovima. Javno mnjenje je nezadovoljno kvalitetom životne sredine i stanjem u saobraćaju. Kao najvažniji zahtev, na prvom mestu ističe se zahtev za zdravljem ljudi, a s tim u vezi i zahtev za održivim razvojem saobraćaja. O ozbiljnosti problema govori i činjenica da se EU uključila u rešavanje saobraćajnih problema preko različitih direktiva i naučno-istraživačkih projekata. Dve mere koje se uglavnom koriste za rešavanje saobraćajnih problema u gradovima su izgradnja ili proširenje postojeće saobraćajne infrastrukture i upravljanje saobraćajnom potražnjom (TDM). Upravljanje saobraćajnom potražnjom je nova paradigma koja ima za cilj smanjenje ili preoblikovanje saobraćajne potražnje kroz smanjenje nepotrebnog korišćenja privatnih vozila i unapređenje efikasnijih, zdravijih i pre svega čistijih oblika javnog i nemotorizovanog prevoza. Postoji čitav niz metoda za upravljanje saobraćajnom potražnjom kao što su sistem „Park\&Ride“, „carpooling“, „,carsharing “, prioritet za vozila sa visokom popunjenošću - HOV, „teleworking“, naplata zagušenja, naplata korišćenja saobraćajne infrastrukture, unapređenje biciklističke infrastrukture i dr. Tema rada je fokusirana na izbor optimalne strategije za upravljanje saobraćajnom potražnjom u Zagrebu primenom višekriterijumske analize.

Ključne reči: upravljanje saobraćajnom potražnjom, višekriterijumska analiza, Zagreb. 